\title{
Determinants of Financial Moroccan Banks Performance: Approach by the Cointegration Method
}

\author{
Sara Bayoud \\ PhD Student, FSJES Souissi, \\ Mohammed V University Rabat, Maroc \\ Nabil Sifouh \\ PhD Student, FSJES Souissi, \\ Mohammed V University Rabat, Maroc \\ Mohamed Chemlal \\ Research Professor, FSJES Souissi, \\ Mohammed V University Rabat, Maroc
}

Doi: $10.2478 / \mathrm{mjss}-2018-0123$

\begin{abstract}
The purpose of this paper is to test the long-term relationship between banks financial performance and two groups of variables, internal variables specific to the bank, and exogenous macroeconomic variables. To appreciate this long-term relationship, we applied the Fully Modified Ordinary Least Squares FMOLS method as a technique for estimation cointegrated panel data. Over a period of 26 semesters (2004 to 2016), our results show that a set of internal variables explains the financial performance of banks. As for external factors, economic growth explains this performance, while inflation has no predictive power of performance at least for our sample of the main Moroccan listed banks.
\end{abstract}

Keywords: Banking performance, ROA, ROE, Cointegration, FMOLS

\section{Introduction}

The banking performance has been the subject of many academic studies in recent years given the peculiarity of the financial system as the engine of economic growth. The empirical literature reveals that banking performance is influenced by determinants of different natures. First of all, it is about internal variables that illustrate management efficiency, these variables concern the strategic choices of the bank, whose commercial policy is the first factor that conditions the performance of a bank as a simple firm that seeks a comfortable positioning in his sector of activity. Then the specificity of the banking activity requires the consideration of other determining factors related to the risky nature of this activity. Indeed banks are subject to constraints of multiple natures, on the one hand, a highly indebted sector suggests the role of variables such as the financial leverage and the financial structure of the bank, on the other hand, the regulatory constraints since the first Basel Accord (1988) impose a heavy risk management system and in particular the credit risk, This makes it legitimate to take this risk into account in explaining fluctuations in the financial and economic profitability of banks as measured by variables such as ROE (Return On Equity) or ROA (Return On Assets). The history of economic research dealing with this subject shows that the banking performance is also explained by exogenous variables related to economic conditions such inflation rate and the gross domestic product growth rate.

Getting a measure of financial performance requires a clear approach, indeed, one of the approaches consists of analyzing the intermediate management balances to make clear the 
different results and know later the origin of the performances according to an accounting vision. Another approach is to analyze costs according to a global vision that seeks to evaluate the whole activity (Koffi, 2005). In addition to these two classical approaches, the ratios method pays particular attention when one examines performance through the use of ratios between magnitudes extracted from the financial statements in order to allow comparisons both in time and in space. Regarding the financial profitability, it is often apprehended by the ROE, the latter being closely linked to the ROA ratio is often considered as a reference indicator to assess the performance according to an accounting and financial vision. Now, what are the factors that can explain the fluctuations of these two ratios?

The empirical literature shows that banks' financial performance is a function of two types of variables. Indeed, one of the first works dealing with this question dates back to the end of the 1980s, when Bourke (1989) shows that, to explain the banking performance, it is necessary to divide the explanatory variables into two groups of variables related to the internal and external mechanisms of determining profitability. This classification will subsequently form the starting point for studies on the determinants of bank performance, as they are internal factors (Berger et al, 2004) and exogenous macroeconomic factors (Al-Tamimi, 2010; Athanasoglou et al, 2008). Researchers from different backgrounds have tried to opt for linear specifications to explain profitability levels by internal and external variables, we quote in this context, the studies conducted by Hancock (1985), Berger (1995), Rouabah ( 2006) and other researchers who are interested in studying these two categories of variables in order to draw the necessary conclusions about the contribution of internal factors in the explanation of the performance, or the sensitivity of banks to macroeconomic shocks by taking exogenous variables into account.

In this context, this study will examine the relationship between the performance of Moroccan banks listed on the Casablanca Stock Exchange CSE, and two groups of explanatory determinants, the first group consists of internal variables related to the size of the bank, commercial efficiency, debt policy and risk taking by the bank. The second group is the growth rate of gross domestic product (GDP) and the inflation rate as exogenous macroeconomic variables. In order to achieve the objective of this work, this paper will be organized as follows: first, we recall the essence of the financial literature devoted to the study of the determinants of bank performance, then we will present our research methodology before devoting the last section to the main conclusions drawn from the results obtained.

\section{Methodology}

To achieve the objective of the study, we note that the econometric literature reveals that the study of long-term relationships between time series has become unavoidable. To characterize this relationship, cointegration tests are among those most suited to a multivariate context. Since the work of Levin and Lin (1992), special interest has been given to the study of non-stationary time series especially when the macroeconomic dimension is added to the specified model (Hurlin and Mignon, 2006).

For the cointegration test we have to respect three essential steps, first we look for the order of integration of the series retained then if the variables have the same order of integration, the second step is to study the long term relationship by testing cointegration, if the cointegration test makes it possible to demonstrate a long-term relationship between the series, the third step is to estimate the cointegration vectors by an appropriate ecometric test.

Our data have two dimensions, a time dimension and a cross-section dimension, so we opt to study stationarity, for unit root tests in panel data, namely the Levin test, Lin and Chu (2002), the test of Im, Pesaran\& Shin (IPS) (2003) and the Hadri test (2000), the null hypothesis is the presence of unit root (Non-Stationary Processe) except for the Hadri test whose null hypothesis is stationarity. To complete our approach, we apply the cointegration tests of Pedroni (1999) and Kao (1999), then, we can estimate the vectors of cointegration if such a long-term relationship is well verified. For this last test we apply the Fully Modified Ordinary Least Square FMOLS (Pedroni 1996).

Our empirical approach will make it possible to identify the determinants of the performance of Moroccan banks listed on the Casablanca Stock Exchange. The data are extracted from the activity 
reports, the financial statements published on the website of the Moroccan Capital Market Authority (Autoritémarocaine du Marché des Capitaux AMMC) and the CSE website. Macroeconomic data concerns, data on the inflation rate, the gross domestic product growth rate. These indicators are taken from Bank Al Maghrib's activity reports. The frequency of the data is half-yearly. For the other variables, the selected ratios were calculated from data extracted from the financial statements published by the Moroccan Capital Market Authority ( Autorité Marocaine du Marché des Capitaux AMMC) and the CSE website.

Over a total period of 13 years, ie 26 semesters, our sample consists of 6 banks listed on the Casablanca Stock Exchange; in this case we have 156 observations for each variable studied. We have chosen banks, and we have shunned other credit institutions to avoid sampling biases if we mix universal banks with other categories of credit institutions.

Dependent variables: According to an accounting vision, two ratios are used to assess the banking performance, the ROE measured by the net income compared to the shareholders' equity, this ratio measures share-holder wealth creation, and the ROA (Net income / total asset) which allows evaluating the profitability of the assets engaged in the activity of the bank.

Referring to the economic literature that has dealt with the issue of the determinants of bank performance (measured from an accounting point of view), we have decomposed the explanatory variables into two groups of variables, internal variables specific to individuals' banks, and exogenous macroeconomic variables.

Internal variables:

$>$ Size of the bank ( Taille de la banque Taille): the size of the bank is valued by the neperian logarithm of its total assets (Kabir, 2006; Al Tamimi, 2010; Choong and Al, 2012);

$>$ Operating profit margin (Marge sur résultat d'exploitation Marge) :

Marge $=\frac{\text { operating Profit ( résultat d'exploitation RE) }}{\text { net banking income (Produit net banacaire PNB) }}$ (Barneto and Gregorio, 2013);

$>$ Leverage ( Levier financier LEV): $\mathbf{L e v}=\frac{\text { Total debt }}{\text { Total assets }}$ (Barneto and Gregorio, 2013);

$>$ Market share (Part de marché PM) : $\boldsymbol{P} \boldsymbol{M}=\frac{\text { bank deposits }}{\text { totaldeposits of the sector }}$ (Belkhaoui et al, 2012) ;

$>$ Bank Risk Taking (Prise de risqué de la banque PR): $\boldsymbol{P R} \frac{\text { ownfundsofthebank }}{\text { totalassestsofthebank }}$ (Belkhaoui et al, 2012 ;Acharaya et al, 2006).

External variables:

$>$ Gross Domestic Product Growth Rate (Taux de croissance du Produit Intérieur Brut PIB) : (Bolt et al, 2012);

$>$ Inflation Rate (Tauxd'inflation Inf) :( Hassan et Bachir, 2003; Ben Naceur, 2009).

\section{Results}

Before presenting the results of the stationarity and cointegration tests, Table 1 presents some descriptive statistics about variables used in this research.

\subsection{Descriptive statistics}

Table 1: Descriptive statistics (dependent and explanatory variables: half-yearly observations between 2004 and 2016)

\begin{tabular}{|c|c|c|c|c|}
\hline Variables & Minimum & Maximum & Mean & Standard Deviation \\
\hline ROA & 0,001 & 0,036 & 0,006 & 0,004 \\
\hline ROE & 0,004 & 0,268 & 0,071 & 0,040 \\
\hline Taille & 7,286 & 8,632 & 7,944 & 0,393 \\
\hline PIB $(\%)$ & $-0,496$ & 2,650 & 0,393 & 0,856 \\
\hline Inf (\%) & $-0,012$ & 0,021 & 0,004 & 0,008 \\
\hline PM & 0,026 & 0,483 & 0,167 & 0,134 \\
\hline PR & 0,028 & 0,432 & 0,101 & 0,061 \\
\hline Marge & 0,003 & 2,819 & 0,423 & 0,283 \\
\hline Lev & 0,543 & 1,484 & 0,792 & 0,103 \\
\hline
\end{tabular}

Source: Authors, excel. 
Table 1 shows that the ROA fluctuates less than the ROE (standard deviation 0.004 for the ROA and 0.04 for the ROE), for the other variables, the GDP growth rate is the most volatile followed by the size of the banks apprehended by the logarithm of the total assets. Overall debt is very high and oscillates around $80 \%$, this is however a characteristic of banking firms. As for the general level of consumer prices measuring inflation, it is relatively weak and stable with a standard deviation of $0.08 \%$. the most interesting is to know the nature of the dependencies between these variables. Table 2 provides this information through the correlation matrix. We note that ROA and ROE are relatively positively correlated (0.536), however, the most significant level of dependence is on size and market share with a significantly positive correlation coefficient $(0.8)$ with a probability of less than 10-4 (number in parentheses). This means that the big banks have a comfortable competitive position in terms of market share.

Table 2: Correlations matrix between dependent and explanatory variables (2004 to 2016)

\begin{tabular}{|c|c|c|c|c|c|c|c|c|c|}
\hline Variables & ROA & ROE & taille & $\begin{array}{l}\text { PIB } \\
\text { en \% }\end{array}$ & $\begin{array}{l}\operatorname{taux} \\
\text { inf } \%\end{array}$ & PM & PR & Marge & lev \\
\hline ROA & \begin{tabular}{|l|}
1 \\
$(0)$
\end{tabular} & \begin{tabular}{|l|}
0,536 \\
$(0,000)$
\end{tabular} & $\begin{array}{l}-0,247 \\
(0,002)\end{array}$ & $\begin{array}{l}0,172 \\
(0,032)\end{array}$ & $\begin{array}{l}0,148 \\
(0,065)\end{array}$ & $\begin{array}{l}-0,043 \\
(0,590)\end{array}$ & $\begin{array}{l}0,237 \\
(0,003)\end{array}$ & $\begin{array}{l}0,206 \\
(0,010)\end{array}$ & $\begin{array}{l}-0,207 \\
(0,009)\end{array}$ \\
\hline ROE & $\begin{array}{l}0,536 \\
(<0,0001)\end{array}$ & $\begin{array}{l}1 \\
(0)\end{array}$ & $\begin{array}{l}-0,079 \\
(0,325)\end{array}$ & $\begin{array}{l}0,207 \\
(0,010)\end{array}$ & $\begin{array}{l}0,150 \\
(0,062)\end{array}$ & $\begin{array}{l}0,163 \\
(0,043)\end{array}$ & $\begin{array}{l}-0,360 \\
(<0,0001)\end{array}$ & $\begin{array}{l}0,171 \\
(0,033)\end{array}$ & $\begin{array}{l}\mathbf{0 , 1 7 7} \\
(\mathbf{0 , 0 2 7 )}\end{array}$ \\
\hline taille & $\begin{array}{l}-0,247 \\
(0,002)\end{array}$ & $\begin{array}{l}-0,079 \\
(0,325)\end{array}$ & $\begin{array}{l}1 \\
(0)\end{array}$ & $\begin{array}{l}-0,263 \\
(0,001)\end{array}$ & $\begin{array}{l}-0,073 \\
(0,366)\end{array}$ & $\begin{array}{l}\mathbf{0 , 8 1 6} \\
(<0,0001)\end{array}$ & $\begin{array}{l}-0,296 \\
(0,000)\end{array}$ & $\begin{array}{l}-0,049 \\
(0,541)\end{array}$ & $\begin{array}{l}0,411 \\
(<0,0001)\end{array}$ \\
\hline $\begin{array}{l}\text { PIB en } \\
\%\end{array}$ & \begin{tabular}{|l|}
0,172 \\
$(0,032)$
\end{tabular} & $\begin{array}{l}0,207 \\
(0,010)\end{array}$ & $\begin{array}{l}-0,263 \\
(0,001)\end{array}$ & $\begin{array}{l}1 \\
\text { (0) }\end{array}$ & $\begin{array}{l}0,066 \\
(0,412)\end{array}$ & $\begin{array}{l}0,000 \\
(1,000)\end{array}$ & $\begin{array}{l}0,204 \\
(0,011)\end{array}$ & $\begin{array}{l}0,001 \\
(0,995)\end{array}$ & $\begin{array}{l}0,113 \\
(0,162)\end{array}$ \\
\hline $\begin{array}{l}\text { taux inf } \\
\%\end{array}$ & \begin{tabular}{|l|}
0,148 \\
$(0,065)$ \\
\end{tabular} & $\begin{array}{l}0,150 \\
(0,062) \\
\end{array}$ & $\begin{array}{l}-0,073 \\
(0,366)\end{array}$ & $\begin{array}{l}0,066 \\
(0,412)\end{array}$ & $\begin{array}{l}1 \\
(0)\end{array}$ & $\begin{array}{l}0,000 \\
(1,000)\end{array}$ & $\begin{array}{l}0,035 \\
(0,661)\end{array}$ & $\begin{array}{l}0,028 \\
(0,729)\end{array}$ & $\begin{array}{l}0,078 \\
(0,330)\end{array}$ \\
\hline PM & $\begin{array}{l}-0,043 \\
(0,590)\end{array}$ & $\begin{array}{l}0,163 \\
(0,043)\end{array}$ & $\begin{array}{l}0,816 \\
(<0,0001)\end{array}$ & $\begin{array}{l}0,000 \\
(1,000)\end{array}$ & $\begin{array}{l}0,000 \\
(1,000)\end{array}$ & $\begin{array}{l}1 \\
(0)\end{array}$ & $\begin{array}{l}-0,218 \\
(0,006)\end{array}$ & $\begin{array}{l}-0,064 \\
(0,429)\end{array}$ & $\begin{array}{l}0,345 \\
(<0,0001)\end{array}$ \\
\hline PR & $\begin{array}{l}0,237 \\
(0,003)\end{array}$ & $\begin{array}{l}-0,360 \\
(<0,0001)\end{array}$ & $\begin{array}{l}-0,296 \\
(0,000)\end{array}$ & $\begin{array}{l}0,204 \\
(0,011)\end{array}$ & $\begin{array}{l}0,035 \\
(0,661)\end{array}$ & $\begin{array}{l}-0,218 \\
(0,006)\end{array}$ & $\begin{array}{l}1 \\
\text { (0) }\end{array}$ & $\begin{array}{l}0,040 \\
(0,620)\end{array}$ & $\begin{array}{l}-0,468 \\
(<0,0001)\end{array}$ \\
\hline Marge & $\begin{array}{l}0,206 \\
(0,010)\end{array}$ & $\begin{array}{l}0,171 \\
(0,033)\end{array}$ & $\begin{array}{l}-0,049 \\
(0,541)\end{array}$ & $\begin{array}{l}0,001 \\
(0,995)\end{array}$ & $\begin{array}{l}0,028 \\
(0,729)\end{array}$ & $\begin{array}{l}-0,064 \\
(0,429)\end{array}$ & $\begin{array}{l}0,040 \\
(0,620)\end{array}$ & $\begin{array}{l}1 \\
(0)\end{array}$ & $\begin{array}{l}-0,057 \\
(0,483)\end{array}$ \\
\hline lev & $\begin{array}{l}-0,207 \\
(0,009)\end{array}$ & $\begin{array}{l}\mathbf{0 , 1 7 7} \\
(\mathbf{0 , 0 2 7 )}\end{array}$ & $\begin{array}{l}0,411 \\
(<0,0001)\end{array}$ & $\begin{array}{l}0,113 \\
(0,162)\end{array}$ & $\begin{array}{l}0,078 \\
(0,330)\end{array}$ & $\begin{array}{l}0,345 \\
(<0,0001)\end{array}$ & $\begin{array}{l}-0,468 \\
(<0,0001)\end{array}$ & $\begin{array}{l}-0,057 \\
(0,483)\end{array}$ & $\begin{array}{l}1 \\
(0)\end{array}$ \\
\hline
\end{tabular}

Source: Authors, excel

\subsection{Stationarity and cointegration test in panel data}

The three tests used to verify the order of integration show that at the $5 \%$ threshold all the variables are integrated of order $1 /$ (1). We thus complete this approach by the cointegration study (Table 3 ).

Table 3: Statistics of cointegration tests of Pedroni (1999) and Kao (1999) (ROE, internal variables and external variables)

\begin{tabular}{|l|c|c|}
\hline Statistics $^{1}$ & Values & p-value ( null hypothesis : no cointegration) \\
\hline$v$-Statistic Panel & $-2,295228$ & 0,9891 \\
\hline Rho-Statistic Panel & $-2,073266^{* *}$ & 0,0191 \\
\hline PP-Statistic Panel & $-7,068432^{* * *}$ & 0,00000 \\
\hline ADF-Statistic Panel & $-4,694032^{* * *}$ & 0,00000 \\
\hline Rho-Statistic Group & $-1,572146^{*}$ & 0,0580 \\
\hline PP-Statistic Group & $-18,06985^{* * *}$ & 0,00000 \\
\hline ADF-Statistic Group & $-6,28064^{* * *}$ & 0,00000 \\
\hline Test de Kao & $-0,341775$ & 0,3663 \\
\hline
\end{tabular}

Source: Authors, Eviews 9

\footnotetext{
${ }^{1}$ Pedroni (1999) developed seven panel cointegration test statistics, four are based on within dimension, and three are based on between dimension. 
Table 4: Statistics of cointegration tests of Pedroni (1999) and Kao (1999) (ROA, internal variables and external variables)

\begin{tabular}{|l|c|c|}
\hline Statistics & Values & p-value ( null hypothesis : no cointegration) \\
\hline v-Statistic Panel & $-1,736419$ & 0,9588 \\
\hline Rho-Statistic Panel & $-2,370129^{*}$ & 0,0089 \\
\hline PP-Statistic Panel & $-7,728802^{* * *}$ & 0,00000 \\
\hline ADF-Statistic Pane & $-8,086025^{* * *}$ & 0,00000 \\
\hline Rho-Statistic Group & $-1,20013$ & 0,1150 \\
\hline PP-Statistic Group & $-11,828678^{* * *}$ & 0,00000 \\
\hline ADF-Statistic Group & $-8,770481^{* * *}$ & 0,00000 \\
\hline Test de Kao & $-0,1924$ & 0,1924 \\
\hline
\end{tabular}

${ }^{\star * *},{ }^{* *},{ }^{*}$ indicate significance level at $1 \%, 5 \%$ and $10 \%$

Source: authors, Eviews 9

At the significance level of $5 \%$, the results of the statistics of the two tests show that the cointegration relationship between ROE and the set of ratios, on the one hand, and between the latter and ROA, on the other, cannot be accepted if retains the Kao test, the values of the test statistic are not significant ( $p$-value less than $5 \%$ ). However, the Kao test has the specificity of being limited to homogeneous data and does not take into account the heterogeneities in the observations.

In contrast to the Kao test, the Pedroni test, through the individual parameters taking into account this heterogeneity (Hrlin and Mignon, 2006), shows that five of the seven statistics proposed by Pedroni are significant at the $1 \%$ level. In other words, the Pedroni test makes it possible to accept the alternative hypothesis of the existence of a long-term relationship between the variables studied. In summary, the decision rule to be taken in practice is to assume the existence of a cointegration relationship if most statistics allow. From these results we can say that on the whole we accept a long-term relationship linking the variables studied.

\subsection{Estimation of cointegration vectors by the FMOLS method}

We complete our approach by estimating the significance of this long-term relationship between the variables in question. In this framework, we use the FMOLS regression method to answer our main question about the main variables explaining Moroccan banks performance (Table 5 and Table 6). The FMOLS method was used by Pedroni to estimate the parameters of the relationship between a dependent variable, and one or more explanatory variables.

Table 5: Estimation of cointégration vectors by the FMOLS method (dependent variable: ROE)

\begin{tabular}{|c|c|c|c|}
\hline Variable & Coffecient & t-statistic & p-value \\
\hline Taille & 0.0093 & $1.9773^{* *}$ & 0.0499 \\
\hline Marge & 0.0041 & $3.4743^{* * *}$ & 0.0007 \\
\hline PM & 0.0162 & 0.5830 & 0.5608 \\
\hline PR & -0.2905 & $-4.2650^{* * *}$ & 0.0000 \\
\hline LEV & -0.0128 & -0.3085 & 0.7581 \\
\hline INF & 0.8015 & $1.8491^{*}$ & 0.0665 \\
\hline PIB & 0.0233 & $4.8868^{* * *}$ & 0.0000 \\
\hline$* * *{ }^{* *}{ }^{*}$ indicate significance level at $1 \%, 5 \%$ and $10 \%$
\end{tabular}

Source: Authors, Eviews 9

Table 5 shows that market share (MP), financial leverage (LEV) and inflation rate are not significant at $5 \%$ threshold (probability greater than $5 \%$ ), while the test statistics (at the significance level of $5 \%$ ) show a significant long-term relationship between ROE and GDP (GDP), Margin, Size and PR 
variables, in other words, the financial performance is positively impacted by the fluctuations of these variables, except for the variable PR or this link becomes negative.

Summarizing these results, we can conclude that the big banks, (significant size) that have the highest operating margins, and when the economic situation is favorable (GDP growth rate), are those that display the best financial performances.

Table 6: Estimation of cointegrationvectors by the FMOLS method (dependent variable: ROA)

\begin{tabular}{|c|c|c|c|}
\hline Variable & Coffecient & t-statistic & p-value \\
\hline Taille & -0.0077 & $-3.2527^{* *}$ & 0.0014 \\
\hline Marge & 0.0028 & $2.3262^{* *}$ & 0.0215 \\
\hline PM & 0.01001 & 1.8173 & 0.1403 \\
\hline PR & 0.0105 & $1.4832^{*}$ & 0.0713 \\
\hline LEV & 0.0011 & 0.2344 & 0.8150 \\
\hline INF & 0.0422 & 1.0475 & 0.2967 \\
\hline PIB & -0.0003 & -0.7054 & 0.4817 \\
\hline
\end{tabular}

\section{Source: Authors, Eviews 9}

Table 6 summarizes the statistics of the estimate of the cointegration vectors between return on assets (ROA) and the two groups of variables retained, it is observed according to the values of the statistics (t-statstic) that, only margin (Marge) and size (Taille) can predict ROA. This result shows that even though the first cointegration test asserts the long-term. relationship between these variables, the FMOLS estimate shows that this relationship is not significant at least for macroeconomic variables (inflation rate and growth rate). This last result indicates that we cannot predict an evolution of the ROA if we retain the same variables chosen in this study. On the other hand, this relationship is significant only for the financial profitability apprehended by the ROE.

\section{Conclusion}

In order to provide some answers to our research problem, we conducted this study with the main listed Moroccan banks over a period of 13 years in the hope of examining the reaction of banking performance to endogenous factors, and to the economic situation.

Overall, our study shows that financial performance is explained by two categories of variables. First, this performance is tied to internal variables that illustrate the commercial effectiveness (operating margins and market share). This first result is consistent with previous studies showing that the banks that hold the market have the ability to increase their profitability (Berger et al, 2000, Goddard and Wilson, 1999, Seelanatha, 2010). The other observation is that the big banking firms record the best financial performances despite a very high debt ratio. This is consistent with the financial literature, as research often links bank size to cost control by assuming scale economies (Goddard, 2001). The other highlight is that there is an inverse relationship between the risk that measures in our case the degree of capitalization of the bank and the financial performance. Among the explanations provided to understand the origin of this negative relationship, Belkhaoui et al (2012) argue that risk-taking reduces the quality of long-term assets by increasing the amount of unpaid bills.

Exogenous factors suggest that inflation does not affect the financial performance of the two ROA and ROE ratios. This is surprising since the majority of studies show a significant relationship between inflation and bank profitability. However, if we have not been able to show a long-term link between the evolution of the consumer price index and the banking performance, economic growth has a better explanatory power than inflation at least for the performance financial. The impact of growth has been studied by neoclassical financial theory which even shows a reciprocal relationship between growth rate and financial development (Jung, 1986).

As we have mentioned, the conclusions of this study confirm the previous results concerning 
the role of many factors in the explanation of the banks' performance especially in its financial dimension, however, this study has not incorporated other types of variables, especially since the last Basel reform known as Basel III. Following this reform, two liquidity ratios were introduced (Bitar and Madies, 2013), Liquidity Coverage Ratio (LCR), and the Net Stable Funding Ratio (NSFR). This is explained by the fact that the subprime crisis is above all a liquidity crisis, hence the interest of introducing (subject to the availability of sufficient data) liquidity risk as an internal determinant to examine in order to better identify the determinants of banking performance.

\section{References}

Acharya, V. V., Hasan, I., \& Saunders, A. (2006). Should Banks Be Diversified? Evidence from Individual Bank Loan Portfolios. The Journal of Business, 79 (3), p. 1355-1412.

Al-tamimi,h.A. (2010). Factors influencing performance of the uaeislamic and conventional national banks. Global journal of business research vol. 4 no. 2.

Athanasoglou, P.P, Brissimis, S.N, and Delis,M.a D. (2008). Bank-specific, industry-specific and macroeconomic determinants of bank profitability, Journal of International Financial Markets, Institutions and Money, Elsevier, vol. 18(2), p. 121-136

Barneto,P., and Gregorio,G. (2013). Determinants of the financial performance of major european banks. Bankers, markets \& investors $n^{\circ} 127$ November-december..

Belkhaoui,S., and Al. (2012). Impact de la structure de marche et du choixstratégique sur la performance bancaire :cas des pays émergents. Revue management international volume 16, numéro 4, été, 2012, p. $129-149$.

Ben Naceur,S., and Goaied,M. (2009). The Determinants of Commercial Bank Interest Margin and Profitability: Evidence from Tunisia. Frontiers in Finance and Economics, Vol. 5, No. 1, p.106-130. Available at SSRN.

Berger, A., DeYoung, R., Flannery, M., Lee, D. and Öztekin, Ö. (2008). How do large banking organisations manage their capital ratios? Journal of Financial Services Research, 34, p.123-149.

Berger,A., IftekharHasan,I., and Klapper, L.F. (2004). Bank concentration and competition: an evolution in the making. Journal of money, credit, and banking, $n^{\circ} 36, p .433-451$.

Berger, A.N., Bonime, S.D., Covitz, D.M., and Hancock, D., (2000). Why are profits so persistent? The role of product market competition, Information opacity and regional macroeconomic shocks, Journal of Banking and Finance, Vol. 24, pp. 1203-1235.

Berger,A. (1995). The relationship between capital and earnings in banking. Journal of money, credit and banking, vol:27, no: 2, p.432-456.

Bitar,M., and Madiès,P. (2013). Les spécificités des banquesislamiqueset la réglementation de Bâle III. Revue d'économiefinancière, p. 293-310.

Bolt, W., De Haan, L., Hoeberichts, M., Van Oordt, M. R., \& Swank, J. (2012). Bank profitability during recessions. Journal of Banking \& Finance, 36(9), p. 2552-2564.

Bourke, P. (1989). Concentration and other determinants of bank profitability in europe. Journal of banking and finance, $n^{\circ} 13$, p.65-79

Choong, Y. V., Thim, C. K., \&Kyzy, B. T. (2012). Performance of Islamic commercial banks in Malaysia: an empirical study. Journal of Islamic Economics, Banking and Finance, 8(2), p. 67-80.

Goddard,J.A., Molyneux.P.M., and Wilson.J.O.S. (2001)."European banking :ef-ficiency, technology and growth, chichester".

Goddard, J., and Wilson, J.O.S., (1999) « Persistence of Profit: A New Empirical Interpretation », International Journal of Industrial Organization, Vol. 17, p. 663-687.

Hadri, K. (2000). Testing for Stationarity in Heterogeneous Panel Data, Econometric Journal, 3, p. 148-161.

Hancock.B, (1985). Bank profitability, interest rates, and monetary policy. Journal of money, credit and banking, vol. 17, no. 2, p. 189-202.

Hassan, M. K., \& Bashir, A. H. M. (2003). Determinants of Islamic banking profitability. In Paper Presented at the Proceedings of the Economic Research Forum (ERF) 10th Annual Conference, Marrakeshe Morocco.

Hurlin.c, Mignon,V. (2006). Unesynthèse des tests de racine unitaire sur données de panel. Economieet prévision, mine- direction de la prévision, 169, p. 253-294.

Im,K.S, Pesaran,M.H, and Shin,Y. (2003). Testing for unit roots in heterogeneous panels. Journal of econometrics, 115,1 , p.53-74.

Jung,W. (1986). Financial development and economic growth: international evidenceconomic development and cultural change. 1986, vol. 34, issue 2, p.333-46.

Kabir. H, M,(2006). The x-efficiency in Islamic banks. Islamic Economic Studies Vol. 13, No. 2, p. 49-78.

Kao.c, (1999). Spurious regression and residual-based tests for cointegration in panel data. Journal of econometrics, 90(1), p.1-44. 
Koffi,J. (2005). Econometric approach of european banks' determinants of profitability. Munich personal repec archive.

Levin,A., Lin,C.F., and Chu.C.S.J. (2002). Unit root test in panel data: asymptotic and finite sample properties. Journal of Econometrics, 108, p.1-24.

Levin.A, and Lin.C.F., (1992). Unit root tests in panel data: asymptotic and önite sample propertiesî. Discussion paper 56, department of economics, university of california at san diego.

Pedroni,P. (1999).Critical values for cointegration tests in heterogeneous panels with multiple regressors. Oxford bulletin of economics and statistics, 61,p. 631-52.

Pedroni,P.(1996). Fully Modified OLS for heterogeneous cointegrated panels and the case of purchasing power parity. Working paper in economics, indiana university.

Rouabah,A.(2006). La sensibilité de l'activité bancaire aux chocs macroéconomiques: uneanalyse en panel sur des données de banques luxembourgeoises. Cahier d'études working paper $n^{\circ} 21$.

Seelanatha,l.(2010). Market structure, efficiency and performance of banking industry in srilanka. Banks and bank system's 5 (1), p.20-3. 